Volume 11

Issue 3 Global Approaches to Atrocity

Prevention: Theory, Practice, and the State of

the Field

3-2018

\title{
Responding to Purdeková
}

Simon Turner

University of Copenhagen

Follow this and additional works at: https://digitalcommons.usf.edu/gsp

\section{Recommended Citation}

Turner, Simon (2018) "Responding to Purdeková," Genocide Studies and Prevention: An International Journal: Vol. 11: Iss. 3: 139-140.

DOI:

http://doi.org/10.5038/1911-9933.11.3.1510

Available at: https://digitalcommons.usf.edu/gsp/vol11/iss3/17

This Book Review is brought to you for free and open access by the Open Access Journals at Digital Commons @ University of South Florida. It has been accepted for inclusion in Genocide Studies and Prevention: An International Journal by an authorized editor of Digital Commons @ University of South Florida. For more information, please contact digitalcommons@usf.edu. 
Responding to Purdeková

\author{
Simon Turner \\ University of Copenhagen \\ Copenhagen, Denmark
}

Andrea Purdeková, in her review of Politics of Innocence: Hutu Identity, Conflict and Camp Life, ${ }^{1}$ asks what the relationship is between the space of the camp, the production of history, and the nature of nationalism that emerges in exile? And, she continues, "how do these tie to the dynamics of ongoing conflict?"

These are important questions that go beyond the scope of my book. As she rightly points out 'more historical depth and a comparative perspective would be useful.' Let me, however, give some suggestions on the matter. In her seminal book Purity and Exile: Violence, Memory, and National Cosmology Among Hutu Refugees in Tanzania, ${ }^{2}$ Liisa Malkki suggests that the kind of ethnic nationalism she found in Mishamo camp, did not appear among the self-settled Burundian refugees that she studied in Kigoma town. These apparently had a more cosmopolitan worldview. Rather than cultivating roots and purity like the camp refugees, they were more rhizomatic in a Deleuzian sense, living in the present and unconcerned with cultural purity. Malkki has indeed been criticized for projecting her own ideals onto these town refugees. I am not able to judge whether this is the case. I have, however, also done fieldwork among Burundian refugees who left Lukole camp to try their luck in Nairobi. While the picture is not as clear-cut, as Malkki suggests, several of the refugees suggested that they left the camp due to its saturation with politics, making individual choices nearly impossible. On the one hand, Nairobi was the hub of communication for opposition parties, while on the other hand, many chose to leave party politics and pursue individual hopes for a better future elsewhere - often strongly attached to charismatic churches. ${ }^{3}$

These findings seem to support the idea that the refugee camp became a place for shaping political ideologies-although I argue against Malkki's findings that they must necessarily be radically ethno-nationalist. One of the main arguments in the book is that there are several, competing ideologies in the camp and that the dominant ideology was relatively 'moderate' and democratic in its outlook. I argue in the book that the answer to this must be found in recent history in Burundi and Rwanda, and therefore that we cannot see the camp in isolation from the outside world and from the history of the region.

The findings also support the idea that refugees outside the camp are less shaped by such political ideologies, although they also maintain relations with the camp and dreams of a different future Burundi-and are therefore not merely rhizomatically living in the present.

So to answer Purdeková's questions: the camps do indeed play a central role in shaping certain political subjectivities that in turn shape the nature of conflict-and peace-in the region. And while the United Nations High Commissioner for Refugees (UNHCR) and other humanitarian agencies seem to be oblivious to this fact and keep on treating refugees as innocent victims, other actors in the region are well aware of the ways in which camps shape political subjectivities. I have written elsewhere how the Rwandan state treated the returning refugees radically different to the international community. ${ }^{4}$ Rather than perceiving the refugees as 'bare life,' lacking political agency, the Rwandan state perceived them as what I have termed 'bad life,' containing harmful political agency that could threaten the post-genocide nation and hence in need of re-education in Ingando camps. Purdeková's own book similarly demonstrates that the Rwandan state does

\footnotetext{
${ }^{1}$ Simon Turner, Politics of Innocence: Hutu Identity, Conflict and Camp Life (Oxford and New York: Berghahn, 2010).

${ }^{2}$ Lisa H. Malkki, Purity and Exile: Violence, Memory, and National Cosmology Among Hutu Refugees in Tanzania (Chicago: Chicago University Press, 1995).

${ }^{3}$ Simon Turner, "Staying out of Place: The being and becoming of Burundians refugees in the camp and the city," Conflict and Society 2, no. 1 (2016), 37-51; Simon Turner, "We Wait for Miracles-Ideas of Hope and Future Among Clandestine Burundian Refugees in Nairobi," in Ethnographies of Uncertainty in Africa (Anthropology, Change, and Development) ed. Elizabeth Cooper et al. (London: Palgrave Macmillan, 2015),173-192.

${ }^{4}$ Simon Turner, "New Citizens and a New Beginning-Repatriation and Nation-building after genocide in Rwanda," Development and Change 45, no.3 (2014), 415-433.
} 
not see its education camps as places for simply containing victims of history without agency, but treats those who enter the Ingando camps as potentially having negative ideas that need removing and replacing with new, patriotic mentalities.

In a sense, Purdeková and I both explore camps as sites of intense identity making. However, the contexts and the foci of our work differ. The Ingando camps were created in the context of a post-genocide regime that was acutely aware of the threat of 'negative mentalities' and bent on creating subjects that were supportive of the new regime. The refugee camp, on the other hand, existed in a context of international humanitarianism that is blind to political subjectivities and more concerned with 'pure victims' devoid of agency - whether negative or positive.

In terms of focus, Purdeková primarily explores the camp from the outside, thus loosing out on the negotiations and repositioning that might take place inside the camp, but demonstrating nicely how the Ingando camps are part of a larger state building project. She is in other words, making an important point about how camps are affected by the surrounding society and how they in affect society. In my book, on the other hand, I have neglected this aspect as Purdeková also remarks. Although I argue that 'the camp was not an island unto itself ${ }^{\prime 5}$ and show how the conflict in Burundi followed the refugees into the camp, my focus was on the internal dynamics of the camp, demonstrating that the refugees transformed the camp into something else than was intended by its planners.

Both views are relevant and both are important, as much scholarships on camps makes the double mistake of firstly treating camps as isolated entities and secondly assuming that the policies of camp planning succeed. Our studies show that one should not assume either and that by understanding camps - in their context as well as from the inside-we may understand a lot about the constitution of society and its conflicts.

${ }^{5}$ Turner, Politics of Innocence, 164. 